\title{
Manfaat Perilaku Spiritual Sufi Pada Kesehatan Mental dan Well Being Seseorang
}

\author{
Saliyo ${ }^{1}$ \\ Sekolah Tinggi Agama Islam Negeri (STAIN) Kudus
}

\begin{abstract}
The purpose of this article is to know the connection of Sufi spiritual behavior with mental health in the form of well-being performed by the spiritual Sufi path. This article explores Sufi spiritual behavior with regard to mental health in the form of well-being that comes from literature.

The method used in this research is qualitative research in the literature review. How to collect research data by researchers by writing, classifying and monitoring subjects of research studies carried out by researchers. Moreover, researchers conducting a survey of data collected related to the subject matter of the research is a spiritual relationship to mental health.

The results of the literary research show that mystical spiritual behavior towards mental health, especially in the field of well-being, remains controversial. Sufi spiritual behavior has a positive effect. On the other hand, there are also results that mystic behavior has a negative effect. This incident occurred because of misunderstanding or perception of Sufi teachings, or lack of good guidance for the person in taking the sufi path.
\end{abstract}

Keywords: Spiritual Sufi; mentally healthy; well being

\begin{abstract}
Abstrak
Tujuan ditulisnya artikel ini adalah untuk mengetahui keterkaitan perilaku spiritual sufi dengan kesehatan mental dalam bentuk well being yang dilakukan oleh para penempuh jalan spiritual sufi. Artikel ini mengeksplorasi tentang perilaku spiritual sufi kaitannya dengan kesehatan mental dalam bentuk well being yang bersumber pada literatur.

Metode yang digunakan dalam penelitian ini adalah metode penelitian kualitatif pada kajian literatur. Cara pengumpulan data penelitian yang peneliti lakukan dengan mencatat, mengklasifikasikan, dan mengobservasi tema-tema kajian penelitian yang peneliti lakukan. Selanjutnya peneliti melakukan pemeriksaan data yang telah terkumpul yang berkaitan dengan tema penelitian yaitu spiritual kaitannya dengan kesehatan mental Hasil penelitian literatur menunjukan bahwa perilaku spiritual sufi terhadap kesehatan mental terutama pada well being masih kontroversi. Ada temuan bahwa perilaku spiritual sufi berpengaruh positif. Sisi lain juga ada temuan bahwa perilaku sufi berefek negatif. Kejadian ini terjadi dikarenakan kesalahan memahami atau mengkonsepsikan ajaran-ajaran sufi, ataupun tidak adanya bimbingan yang baik bagi orang tersebut dalam mengambil jalan sufi.

${ }^{1}$ Korespondensi untuk tulisan ini ditujukan kepada email saliyo72@yahoo.com
\end{abstract}


Kata kunci : Spiritual Sufi; Kesehatan Mental; well being

\section{Pendahuluan}

Psikologi merupakan ilmu pengetahuan yang mempelajari tentang jiwa atau psikis seseorang. Berbicara mengenai eksistensi manusia secara fisik dan tampak dapat diukur, namun secara psikis memang keberadaan eksistensi manusia sulit diukur. Seiring dengan perkembangan teknologi dan perkembangan ilmu psikologi keberadaannya mampu menjawab bahwa eksistensi psikis manusia dapat diukur. Sisi lain ilmu psikologi berkembang secara pesat dengan berbagai pandangan. Pandangan perkembangan ilmu psikologi tersebut muncul dengan istilah aliran Psikologi Psikoanalisis, Behavioristik, Humanistik dan Transpersonal. Aliran pandangan Psikologi Transpersonal lebih dekat dengan pandangan berdasarkan pendekatan agama. Selanjutnya muncul juga aliran psikologi yang berdasarkan pada ajaran agama Islam, maka aliran tersebut dinamakan Psikologi Islam.

Integrasi ilmu pengetahuan berbasis agama menjadi jawaban kebutuhan zaman. Kebutuhan atas jawaban permasalahan yang dihadapi manusia dengan berdasarkan agama. Psikologi Islam merupakan jawaban atas permasalahan permasalahan psikis manusia yang berpijak pada pandangan agama Islam. Hal tersebut berdasarkan atas universalitas Islam.

Menurut Shihab (Shihab, 1992) bahwa universalitas Islam memiliki makna bahwa ajaran Islam berlaku untuk seluruh umat Islam di dunia sebagai akidah. Walaupun ada perbedaan dalam budaya namun dalam sisi nilai akidah ajaran Islam memiliki kesamaan. Memperkuat pendapat di tersebut, Sayid Qutub menjelaskan bahwa ajaran Islam memiliki semangat yang menjelaskan tentang rabbaniyah (keTuhanan), al-Syumul (keumuman), dan al-Waqi'iyah (kenyataan). Allah SWT berfirman dalam al-Qur'an surat ar-Rum (30 : 30). Fitrah manusia pada dasarnya adalah beragama. Agama yang benar dan Tuhan menurut fitrah manusia adalah agama Islam yang berTuhankan dengan Allah SWT. Sayangnya banyak manusia yang lalai.

Penjelasan tersebut dapat memperkuat pemenuhan kebutuhan akan hadirnya ilmu pengetahuan yang memiliki makna ke Tuhanan. Kebutuhan yang demikian bahwa Islam sebagai pijakan ilmu pengetahuan memiliki pesan yang jelas yaitu adanya kenyataan, keumuman serta keTuhanan. Ilmu pengetahuan yang dibangun atas dasar nilai keTuhanan 
akan mendukung bagi penambahan keimanan seseorang yang meggunakan ilmu tersebut. Makna kenyataan dan keumuman bahwa kebutuhan akan hadirnya ajaran Islam sebagai dasar pembedah ilmu pengetahuan psikologi sudah tidak diragukan lagi. Alasannya bahwa pemeluk agama Islam di dunia termasuk penganut yang besar. Sisi lain ilmu pengetahuan bagaikan senjata yang bermata dua seperti pisau. Satu sisi pisau yang tajam ataupun senjata yang dapat membunuh seseorang, dan sisi yang lain dapat digunakan untuk kebaikan. Sama dengan ilmu pengetahuan, apabila ilmu pengetahuan tersebut dibangun atas dasar nilai-nilai moral keTuhanan, maka ilmu pengetahuan tersebut akan banyak bermanfaat bagi makhluk hidup di dunia ini.

Uraian tersebut sebenarnya telah diprediksi oleh ilmuan dari Amerika yaitu Samuel Huntington (Ahmed, 1993) tentang akan adanya konflik peradaban secara internasional. Konflik tersebut tidak hanya secara wilayah politik (geopolitic) dan wilayah budaya (geoculture). Konflik tersebut seputar tentang pandangan peradaban antara Barat versi keistimewaannya (West versus East). Konflik tersebut sebenarnya bukanlah ide pengisolasian intelektual dari Amerika. Konflik tersebut lebih menekankan tentang isu-isu keyakinan secara internasional yang penekanan utamanya pada dasar dasar budaya dan filosofis. Keadaan yang demikian merupakan ujian bagi pemeluk agama Islam untuk mampu menjelaskan apakah ajaran Islam merupakan agama atau budaya? Apakah ajaran agama Islam merupakan sesuatu yang istimewa yang dapat menjawab segala persoalan zaman? Keadaan yang demikian diperkuat lagi oleh Samuel Huntington bahwa konflik peradaban akan meningkat dan terpusat antara Barat dan Islam, peradaban Islam dan Hindu di India, peradaban Islam dan peradaban Slavic ortodok di Rusia, peradaban Cina dan Jepang. Isu - isu demikian merupakan tema yang muncul secara internasional (Ahmed, 1993).

Kehadiran Psikologi Islam sebagai ilmu pengetahuan merupakan usaha untuk mengejawantahkan nilai-nilai Islam dalam ilmu psikologi. Hal yang demikian tidak perlu diperdebatkan lagi. Sisi lain kehadiran ilmu Psikologi Islam juga merupakan penanaman nilai moral agama yang bersifat keTuhanan bagi pemeluknya untuk menjawab berbagai persoalan yang ada di dunia.

Memperbincangkan Psikologi Islam tentu akan memperbincangkan Islam sebagai 
keyakinan agama manusia. Mengupas akar istilah masalah keyakinan ada istilah religiusitas dan ada istilah spiritualitas. Istilah religiusitas lebih memiliki makna pada keyakinan yang bersifat formalistik. Sisi lain istilah spiritualitas lebih pada keyakinan yang bersifat personalistik, substantif. Uraian ini diperkuat dengan penjelasan bahwa agama merupakan organisasi komunitas masyarakat yang terstruktur berkaitan dengan tradisi keimanan. Secara umum agama memberikan perhatian pada kitab suci, doktrin nilai-nilai keimanan. Spiritual digambarkan sebagai suatu perhatian seorang manusia terhadap sesuatu yang suci berkaitan dengan konsep keyakinan dan kekuatan yang lebih tinggi. Kekuatan yang lebih tinggi memiliki makna Tuhan. Pargament mendefinisikan spiritual sebagai pencarian yang suci. William James mendefinisikan spiritual berkaitan dengan istilah perasaan, aksi, dan pengalaman individual manusia dari ketersendirian atau dari keadaan kesunyian bersama Tuhan (Plante, 2008)

Spiritual memiliki makna yang sangat beragam. Umumnya spiritual memiliki makna seseorang yang melakukan hubungan dengan Tuhannya. Hubungan tersebut bersifat personal. Ajaran-ajaran yang dilaksanakan juga bersifat personal. Keyakinan spiritual juga bersifat personal, namun keyakinan tersebut dapat ditransformasikan kepada orang lain yang dapat menerimanya. Di antara spiritual yang ada dalam Islam adalah spiritual dengan menjalani perilaku sufi (Saliyo, 2017).

Dalam realita kehidupan agama Islam ada istilah Islam itu sendiri yang dekat dengan istilah religiusitas dan ada istilah spiritual yang cenderung dengan perilaku sufi. Memahami Islam ada istilah yang saling berdekatan yaitu Islam, iman, ikhsan, dan agama. Istilah-istilah tersebut dijelaskan oleh Syeikh Kurdi dalam kitab Tanwirul Qulub bahwa Islam menetapkan dan meyakini secara lisan bahwa segala sesuatu yang datang kepada Nabi Muhamad dengan meyakini Allah SWT sebagai Tuhan Yang Esa dan Muhammad ditetapkan sebagai Nabi dan utusanNya. Keyakinan tersebut diucapkan dengan lisan yang dikenal dua kalimah syahadat. Iman adalah membenarkan dengan hati. Artinya bahwa seseorang yang beriman meyakini agama yang dibawa nabi Muhamad, keEsaan Allah SWT, Hari Kebangkitan, dan Hari Pembalasan. Seseorang yang beriman menerima dan melaksanakan kewajiban shalat, menunaikan zakat, haji, dan menjauhi hal-hal yang haram seperti minum-minuman khamr, makan harta riba, dan melakukan zina dan lain sebagainya. Istilah lain adalah ikhsan. Ikhsan 
memiliki makna seseorang yang menyembah Tuhannya seakan-akan dia (Allah SWT) melihatnya, namun apabila orang tersebut tidak mampu, maka orang tersebut dalam beribadah seakan-akan melihat Allah SWT. Sebenarnya hakikat ikhsan adalah mendekatkan diri kepada Allah SWT dengan cara melakukan ibadah. Seseorang yang mampu mencapai ikhsan dalam melakukan ibadah orang tersebut memiliki iman dan Islam dan semua itu dilakukan dengan ikhlas. Adapun istilah agama itu sendiri memiliki makna syari'at yang cenderung memiliki makna Esa. Artinya meyakini dan membenarkan syariat Allah SWT sebagai Tuhannya yang diturunkan kepada Nabi Muhammad sebagai utusanNya untuk dijadikan hukum (al-Kurdi, t.t.).

Realitas yang selanjutnya yang ada dalam pemeluk agama Islam adalah orang-orang yang mengambil jalan sufi. Pada umumnya bahwa agama secara formal hanya dapat menghukumi sesuatu yang tampak. Berbeda dengan penempuh jalan sufi bahwa perilaku seseorang ataupun hukum tidak hanya dilihat secara kasad mata saja, tetapi dilihat dari sisi batinnya. Lebih jelas lagi bahwa perilaku penempuh jalan sufi yang menjadi pilihan seseorang merupakan sisi batin atau dikenal dengan esoterik dalam agama Islam. Sebaliknya penempuh peribadatan dengan ajaran formal agama Islam merupakan sisi dhahir. Secara ringkas bahwa perilaku sufi terpusat dalam hatinya. Bagi seseorang penempuh jalan sufi hati merupakan ruhnya atau spiritnya dalam setiap langkah detak jantungnya orang-orang penempuh jalan sufi. Lebih rinci lagi bahwa perilaku sufi walaupun tiada keterangan atau petunjuk dalil yang pasti untuk mendekatkan diri kepada Allah SWT, kecuali hanya mengikuti rasul dengan secara sempurna. Perilaku sufi dalam mengikuti rasul dalam rangka ibadah dalam bentuk perbuatan ataupun perkataan, ataupun mengikuti para pengikut rasul. Hal tersebut semata-mata menjaga sunah rasul dan etika dalam beribadah serta wujud dari kecintaan seseorang penempuh jalan sufi terhadap Allah SWT.

Cukup jelas bahwa psikologi umum hanyalah membahas perilaku-perilaku manusia yang bersifat dhahir atau tampak. Perilaku manusia yang tampak merupakan perwujudan dari apa yang ada dalam otak manusia tersebut. Hal tersebut dikaji dalam neuropsikologi. Neuropsikologi merupakan pengetahuan dan pemahaman tentang perilaku manusia. Sebagai contoh dari neuropsikologi adalah emosi ditinjau dari konteks fisiologi otak serta kemampuan 
dalam penerapannya dan pengobatan individu yang mengalami gangguan psikologi. Dimensi psikologi mempengaruhi fungsional otak. Begitu sebalik gangguan pada otak akan mempengaruhi psikologi (Ikrar, 2015)

Perilaku sufi merupakan bagian dari perilaku yang memberikan efek ketenangan pada otak orang tersebut. Ketenangan seseorang dapat direkam melalui keadaan otak orang tersebut. Perekaman otak menggunakan alat rekam otak EEG(Electroencapalograpy). Ketika seseorang dalam keadaan tenang, maka gelombang otak orang tersebut dalam kondisi alfa. Seseorang yang kondisi otaknya dalam kondisi alfa orang tersebut dapat relaksasi. Relaksasai merupakan keadaan keterpaduan antara otak dan otot. Otak yang mengalami kecapaian ketika relaksasi dibuat tenang, dan otot yang tegang dibuat rileks. Jika seseorang telah melakukan relaksasi, maka fisiknya menjadi segar dan otaknya siap bekerja kembali dengan energi yang baru. Ketika seseorang dapat melakukan relaksasi, maka pada saat itu panca indra, pernapasan, aliran darah (system kardiovaskuler) otak, dan otot-otot mengalami ketenangan (Pasiak, 2015).

Dari uraian tersebut dapat disimpulkan bahwa perilaku yang kelihatan biasanya karena ada stimulus yang bersifat eksternal. Selanjutnya perilaku yang demikian karena merespon stimulus yang tampak. Perilaku yang demikian karena ingin dilihat hebat, dipuji, menunjukan kebaikannya. Apabila tidak tercapai dari perilaku yang diharapkan dimungkinkan akan melahirkan kemarahan, sedih, kecewa. Keadaan yang demikian dapat menjadikan tidak stabilnya emosi, mental dan well being seseorang. Sebaliknya semangat perilaku sufi karena stimulus internal atau hati. Perilaku yang demikian tidak membutuhkan pujian, sanjungan, ataupun apresiasi. Walaupun dihina ataupun dipuji orang bagi penempuh jalan sufi tidaklah terlalu berpengaruh banyak bagi dirinya. Hal yang demikian akan tetap melahirkan kestabilan emosi. Itulah perbedaan titik tekan kajian psikologi umum Barat dan Psikologi Sufi. Orangorang penempuh jalan sufi diasumsikan akan lebih sehat secara mental ataupun fisiknya dan sejahtera psikisnya. Alasannya karena dalam setiap langkah dan denyut jantung nafasnya karena cinta kepada Allah SWT. Orang-orang sufi sering melakukan dzikir ataupun ibadah yang dapat mencapai relaksasi. Seseorang yang sering relaksasi, maka akan sehat mentalnya dan baik well being orang tersebut.

\section{Metode}


Peneliti menulis artikel ini menggunakan pendekatan penelitian kualitatif. Peneliti melakukan penelitian pada objek kajian literatur. Peneliti melakukan penggalian data pada literatur buku, dan jurnal baik digital ataupun yang manual. Literatur tersebut yang membahas tentang spiritual sufi, well being, dan kesehatan mental. Peneliti melakukan penggalian pada sumber data primer dan sekunder. Sumber data primer berupa buku, dan jurnal yang membahas spiritual sufi, well being dan kesehatan mental. Pendukung data peneliti dapatkan pada sumber data sekunder pada buku dan jurnal yang mengkaji tema penelitian ini.

Cara pengumpulan data penelitian yang peneliti lakukan dengan mencatat, mengklasifikasikan, dan mengobservasi tema-tema kajian penelitian yang peneliti lakukan. Kerja selanjutnya peneliti melakukan editing, dengan cara melakukan pemeriksaan data yang telah terkumpul yang berkaitan dengan tema penelitian spiritual kaitannya dengan kesehatan mental.

Setelah data terkumpul dan dilakukan editing, pemeriksaan klasifikasi dan observasi langkah selanjutnya peneliti melakukan analisis dalam penelitian kualitatif literatur dengan pola deduktif dan induktif. Menurut Hadi bahwa gambar kaitan berpikir deduktif dan induktif disajikan oleh Azwar diadaptasi dari Elmes, Kantowitz, \& Roediger sebagai berikut:

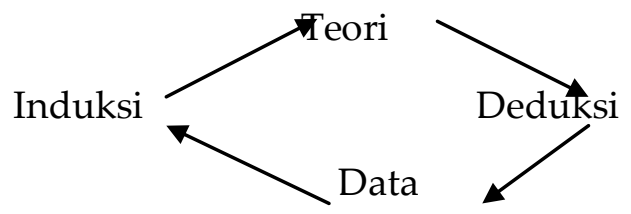

Gambar : 1 Teori mengorganisasi data disajikan oleh Azwar (1997) diadaptasi dari (Elmes, Kantowitz, \& Roediger, 1992).

Berpikir deduktif adalah berpikir yang proses pembuktiannya dari satu atau beberapa pernyataan. Penalaran deduktif kesimpulannya menyajikan dari fakta yang umum menuju fakta yang khusus. Penalaran induktif kesimpulannya menyajikan dari fakta yang khusus menuju fakta yang umum. Penyajian hasil penelitian ini peneliti menggunakan narasi deskriptif dari makna-makna peneliti dapatkan dengan pola deduktif induktif.

\section{H a s i 1 dan Pembahasan}

\section{Perilaku Sufi Perilaku Spiritual}


Hari ini keyakinan agama ataupun spiritual menjadi bagian dari gaya hidup dan perilaku manusia yang penting dalam kehidupan masyarakat. Dos dan Taboos (Kosshal, Kolahdouzan, \& Sharifi, 2013) mengatakan bahwa untuk mendapatkan pemenuhan ilmu pengetahuan agama ataupun spiritual dapat melalui mengamati merasakan perilaku moral agama dan spiritual yang tumbuh subur dan berkembang di masyarakat. Kata lain bahwa perasaan dan keyakinan agama ataupun spiritual dapat teridentifikasi dalam tujuan kehidupan seseorang.

Tasawuf merupakan perilaku pilihan seseorang sebagai gaya hidup dalam beragama baik dilakukan secara pribadi atau kelompok. Perilaku-perilakunya lebih banyak mengedepankan ritual-ritual. Perilaku tasawuf merupakan bagian dari perilaku spiritual, karena perilakunya tidak senang menunjukan kebaikannya kepada orang lain. Ibadah-ibadah atau kebaikan yang dilakukan orang-orang sufi dilakukan dengan senang dan secara rahasia, karena takut riya, tidak ikhlas, dan mengharapkan pujian dari orang lain (Yamani, 2010)

Tujuan akhir tasawuf adalah pengalaman hidup tentang pertemuan secara internal individu dan menyatukannya dengan Tuhannya yang tak tebatas. Pengalaman tersebut diformalisasikan melalui ujian kesadaran. Pengalaman spiritual sufi merupakan hasil dari kontemplasi mistik individu yang independen dari ibadah yang dilakukannya. Kehidupan tersebut merupakan rahmat dari Tuhan dan kecintaan seorang pelaku sufi terhadap Tuhannya (Arkound, 1995).

Seseorang yang mengambil jalan sufi orang memiliki tujuh kriteria. Pertama dalam menjalani kehidupan seorang pengambil jalan sufi selalu berpegang teguh kepada Allah SWT. Kedua orang tersebut selalu makan barang yang halal. Ketiga orang tersebut menjauhi perbuatan maksiat. Keempat orang tersebut mengikuti sunah rasul. Kelima orang tersebut menerima dalam menjalani penderitaan. Keenam orang tersebut selalu melaksanakan taubat, dan ketujuh orang tersebut selalu melakukan kebenaran. Tujuh prinsip-prinsip tersebut merupakan pegangan bagi seseorang yang mengambil jalan kehidupan sufi. Apabila salah satu dari tujuh prinsip tersebut dilakukan oleh seseorang pengambil jalan sufi, maka orang tersebut belum dikatakan telah mengambil jalan sufi (Yamani, 2010).

Tujuh prinsip perilaku sufi tersebut merupakan perilaku yang menyehatkan secara jasmani maupun mental. Seseorang yang menjalankan perilaku sufi yang dapat merusak 
jasmani dan mental karena dimungkin memiliki harapan-harapan di atas akal nalar manusia. Sisi lain orang tersebut dalam menempuh jalan tersebut tanpa bimbingan dari seorang guru (Syeikh/Mursyid).

\section{Kesehatan Mental dan well being dalam Pandangan Spiritual}

Sehat dan sakit adalah keadaan biopsikossial yang menyatu dengan kehidupan manusia. Mendefinisikan sehat secara universal untuk diterima oleh semua orang memang sulit. Konsep sehat menurut World Health Organization (WHO) dalam paparan yang sangat kompleks. Paparan tersebut merupakan penjelasan keadaan yang sempurna baik fisik mental maupun sosial. Pengertian yang ditawarkan oleh WHO merupakan keadaan yang ideal. Artinya bahwa yang dinamakan seseorang dalam kondisi sehat karena di dukung dari sisi psikologis, biologis dan sosial. Sebaliknya ada istilah sakit. Sakit ditelaah secara bahasa dalam bahasa Inggris ada tiga kata yaitu : disease, illness, dan sickness. Menurut Calhoun bahwa tiga kata tersebut memiliki makna secara spesifik. Disease memiliki sakit secara biologis. Illness memiliki makna sakit secara psikologis, dan sickness memiliki makna sakit secara sosiologis.

Paparan tersebut diperkuat dengan penjelasan bahwa di abad 20 banyak penyakit kronis disebabkan karena gaya hidup. Penyakit tersebut diistilahkan dengan illness. Penyakit tersebut muncul dari pola hidup tidak sehat seperti suka merokok, minum-minuman keras, kerja dengan kondisi duduk yang waktu lama, dan makan dengan takaran yang berlebihan. Istilah yang lain berkaitan dengan penyakit yaitu desease. Desease (sakit) muncul akibat dari pola hidup illness. Penyakit dari desease muncul dalam bentuk penyakit hipertensi, diabet, kanker. Pemulihan penyakit demikian memerlukan perlakuan dalam waktu yang cukup lama dan memperbaiki pola hidup yang dijalani oleh pasien.

Dari paparan sebelumnya dapat di ambil kesimpulan bahwa seseorang dikatakan sehat dapat dilihat dari sisi sehat secara psikologis, biologis, dan sosial. Tiga faktor tersebut saling mempengaruhi dalam perilaku seseorang baik dalam kondisi psikologis, biologis ataupun sosial. Kondisi yang demikian merupakan kondisi yang ideal, bagi seseorang dikatakan sebagai orang yang sehat. Namun apabila ditelisik secara lebih mendalam lagi masih ada faktor yang belum tergali yaitu faktor spiritual. 
Seiring dengan zaman yang memasuki zaman modern nilai-nilai spiritual mulai terabaikan. Kebutuhan yang dikejar dan dicari oleh manusia lebih banyak mengedapankan halhal yang berkaitan dengan material. Kondisi yang demikian kebutuhan ruhani manusia berkaitan dengan spiritual mengalami kegersangan. Hal tersebut karena tidak semua setiap manusia dapat memenuhi kebutuhan manusia secara material dan tidak dimbangi oleh pemenuhan kebutuhan spiritual. Keadaan yang demikian dapat mengakibatkan gangguan jiwa pada orang tersebut. Hasil studi World Bank pada tahun 1995 di beberapa negara menunjukan bahwa hari-hari produktif yang hilang atau Dissability Adjusted Life Years menunjukan bahwa $81 \%$ dari Global Burden of Desease disebabkan oleh masalah kesehatan jiwa. Angka tersebut lebih tinggi daripada masalah penyakit Tuberculosis (7,2\%), Kanker (5,8\%), Penyakit Jantung $(4,4 \%)$, dan Malaria $(2,6 \%)$.

Pada beberapa abad yang lalu sebenarnya aktivitas spiritual yang memberikan manfaat pada kesehatan fisik sebenarnya sudah dikenal sejak lama. Di antara manfaat spiritual adalah dapat memperpanjang umur seseorang yang menjalankannya. Hasil meta analisis paling tidak ada 42 studi penelitian yang menguji hubungan antara kematian seseorang dengan aktivitas spiritual seseorang. Hasilnya menunjukan bahwa seseorang yang hidup dalam lingkungan spiritual umurnya lebih panjang daripada dengan teman sebayanya yang berada dalam lingkungan spiritual yang kurang baik. Hasil penelitian yang lain menunjukan bahwa kebermanfaatan seseorang yang menjalankan spiritual dapat mengurangi penyakit jantung, AIDS, dan kangker (Cornah, 2006).

Akhir-akhir ini perubahan telah dimulai pada agama Kristen bahwa ada hubungan antara spiritual dan kesehatan mental. Hubungan tersebut banyak dikaji dalam bidang Psikologi, Psikiatri, Gerontologi, dan Keperawatan. Secara intrinsik bahwa perilaku spiritual memiliki hubungan yang positif terhadap individu tersebut. Pada tahun 1997 Mental Health Foundation melakukan survei menghasilkan bahwa keyakinan agama ataupun spiritual sangat penting dan positif dalam mendukung kesehatan mental seseorang. Dengan demikian untuk mendukung terwujudnya kesehatan mental, maka perlu adanya bimbingan spiritual ataupun agama untuk mencapai tujuan hidup, penyesuaian hidup, ekspresi seseorang yang mengalami sakit dan pengembangan cinta seseorang terhadap yang lain (Levin, 2010). 
Dalam ajaran agama Islam masalah penyakit juga sebenarnya juga telah banyak dikaji. Secara bahasa penyakit dalam bahasa Arab dinamakan al-maradh. Lawan kata dari al-Maradh adalah as-Sihah. As-Sihah memiliki makna keadaan seseorang yang selamat dari pengaruh perbuatan yang baik atau kebiasaan-kebiasaan yang baik yang mempengaruhi perkembangan seseorang. Artinya orang tersebut sehat dalam perkembangannya secara psikis, biologis, sosial dan spiritual. Sisi lain al-Maradh memiliki makna suatu kondisi sakit atau tidak normal sehingga menimbulkan kerusakan-kerusakan yang tidak selayaknya pada orang tersebut. $A l$ Maradh adalah kondisi tidak normal yang menimpa pada tubuh manusia yang mengindikasikan adanya penyakit. Allah SWT berfirman dalam al-Qur'an surat as-Syua'ra (26 : 80). Ayat tersebut memberikan petunjuk bahwa nabi berkata bahwa apabila beliau sakit maka Allah SWT yang akan menyembuhkannya. Artinya bahwa setiap penyakit ada obatnya. Ayat tersebut memberikan pesan bahwa ketika seseorang mengalami sakit untuk selalu memiliki sikap optimis, sabar, dan selalu berobat agar mendapatkan kesembuhan.

Pada abad 20 ada banyak literatur ilmu psikologi yang berpengaruh terhadap agama. Pengaruh tersebut muncul pada metode psikoterapi oleh Sigmund Freud yang dikenal dengan Psikoanalisis. Praktik dan teori yang dikenalkan oleh Freud berasal dari pengalamannya sendiri ketika mengobati pasien-pasienya yang mengalami gangguan mental ringan yang diklasifikasikan sebagai penyakit "psikoneurosis." Penyakit tersebut meliputi histeria dengan tanda-tanda disebabkan oleh gangguan mental. Gangguan mental tersebut selanjutnya menimbulkan gangguan organik seperti kelumpuhan, mati rasa, gangguan lambung, kecemasan, rasa takut, dan tindakan yang lain yang dilakukan secara tidak sadar (Thouless R. H, 1995).

Sigmund Freud (1856-1939) belajar ilmu kedokteran di Universitas Viena (Wina) dan tertarik pada pengobatan penyakit syaraf. Tahun 1885 dia pergi ke Paris untuk mempelajari metode-metode aliran Nancy dibawah bimbingan Charcot. Dia sendiri menerapkan pengobatannya dengan metode hipnotis dan dipadukannya dengan asosiasi bebas dan tafsir mimpi. Esensi dari metode penyembuhan yang dilakukan oleh Freud dengan cara menyuruh pasiennya berbicara secara bebas tanpa dihalang-halangi mengenai persoalan-persoalan mereka sendiri. Dengan cara ini persoalan yang sebelumnya tidak diketahui, atas petunjuk 
analisisnya dapat dijelaskan kepada pasien yang bersangkutan. Persoalan yang belum diketahui yang dialami oleh pasien dinamakan sistem alam bawah sadar. Penyembuhan dengan teknik psikoanalisis sebab yang semula di bawah sadar menjadi sadar. Ketika penyakit tersebut sudah masuk dalam wilayah sadar, maka pasien dapat dirawat dengan keadaan sadar (Thouless R. H, 1995).

Pandangan yang lain bahwa agama menyediakan pandangan tentang makna hidup. Hanya agama ataupun spiritual yang dapat menjawab tentang pertanyaan-pertanyaan masalah makna hidup seseorang. Dia berpendapat bahwa keimanan agama ataupun spiritual dapat membantu neurosis yang diderita seseorang. Freud berpendapat bahwa agama merupakan metode yang tepat untuk mengarahkan insting yang dimiliki oleh manusia. Lebih jauh lagi menurut dia bahwa kebutuhan akan agama dan spiritual merupakan kebutuhan yang sudah bersifat extraordinary bagi pasien yang mengalami neurosis. Walaupun demikian agama memiliki kebermanfaatan positif bagi mental seseorang, tetapi juga memiliki sisi negatif (Koenig, 2001).

Terdapat sejumlah hasil review penelitian agama dan kesehatan mental pada jurnal yang telah dipublikasikan di American Journal of Psychiatry yang dilakukan oleh Victor Sanua. Dia adalah seorang professor di Departement of Social and Psychological Foundation di sebuah Universitas yang berada di kota New York. Dia menjawab tentang pertanyaan agama ataupun spiritual berdampingan dengan agama. Ada anggapan bahwa agama ataupun spiritual merupakan instrumental yang baik untuk seseorang mendapatkan well being, kreativitas, kejujuran, dan liberalism. Sebaliknya menurut Scott \& Godin tidak ada studi yang menunjukan bahwa agama mampu memberikan layanan pada kesehatan mental (Koenig, 2001).

Uraian sebelumnya menjelaskan bahwa kesehatan mental berkaitan dengan dimensi psikologis, sosial, lingkungan dan spiritual. Walaupun dalam aspek spiritual atau agama masih ada ruang perdebatan. Artinya bahwa seseorang yang menganut spiritual ataupun agama tertentu dapat mengakibatkan mental yang tidak baik. Sebaliknya beragama yang berkualitas akan mendukung seseorang untuk memperoleh kesejahteraan psikologis, makna dan tujuan hidup, kejujuran, kreativitas dan berpikir kritis.

Penelitian selanjutnya peneliti mencoba memahami bagaimana dan mengapa agama dan 
spiritual berkaitan dengan well being. Diketahui bahwa mekanisme pelaksanaan adalah mengkritik agar mempromosikan well being (kesejahteraan psikologis) bersifat intern pemeluk agama, bukan di luar konteks pemeluk agama. Sebuah penelitian menguji teori-teori agama yang berefek pada well being telah dilakukan oleh Hayward \& Krau. Hasil penelitian tersebut menghasilkan dua katagori secara umum. Pertama bahwa sumber-sumber sosial dari agama adalah identifikasi dan menerima dukungan agama secara kelompok. Kedua sumber-sumber kognitif dari agama adalah rasa pertalian antar anggota yang baik dan mendapatkan makna.

\section{Manfaat Perilaku Sufi pada Kesehatan Mental dan Well Being}

Akhir-akhir ini menurut Ellison \& Levin (Levin, 2010) ada temuan bahwa agama ataupun spiritual memiliki hubungan dengan kesehatan. Keadaan yang demikian menjadi sesuatu yang menarik bagi psikologi bidang klinis. Hasil review menunjukan bahwa tema keterkaitan antara agama ataupun spiritual masuk dalam dunia akademik, cukup terkenal dan fokus pada bidang sosial, perilaku, epidemiologi dan penelitian klinis dengan jumlah ribuan artikel. Di antara pengaruh agama ataupun spiritual terhadap kesehatan mental seperti gangguan mood yaitu Depresi, dan Kecemasan. Sisi lain agama ataupun spiritual berkaitan dengan kesehatan mental dalam bentuk kesejahteraan psikologis. Di antara bentuk kesejahteraan psikologis adalah kepuasan hidup, kebahagiaan. Sisi lain agama ataupun spiritual juga berpengaruh terhadap bentuk-bentuk yang merusak perilaku seperti kecanduan terhadap zat adiktif dan pemanfaatan kesehatan mental (Levin, 2010).

Pendekatan spiritual pada seseorang yang mengalami sakit mental di mulai sejak masa kanak-kanak. Keadaan yang demikian terjadi juga di Eropa. Walaupun demikian masih ada kontroversi apakah ada integrasi antara perilaku spiritual yang dilakukan seseorang sekaligus sebagai perlakuan bagi seseorang yang mengalami sakit mental?. Pendapat yang masih ragu memiliki alasan karena mereka masih melihat efek samping dari seseorang yang terlibat dalam kegiatan spiritual ataupun agama. Satu sisi pendapat yang mendukung bahwa seseorang yang mengambil jalan spiritual ataupun agama memiliki keuntungan yang positif dalam pandangan gangguan psikiatrik. Fenomena yang seperti itu bila dipahami dengan saksama memang spiritual merupakan dimensi yang unik bagi manusia. Seseorang yang mengambil jalan 
spiritual dapat mengambil makna-makna yang suci dengan penuh makna. Perilaku yang demikian dapat dijadikan sebagai sarana pemulihan bagi pasien yang mengalami gangguan (Hefti, 2011).

Pemenuhan kebutuhan spiritual seseorang yang mengalami sakit mental lebih menekankan pada pemahaman bahwa agama ataupun spiritual dapat menjadi alternatif untuk menumbuhkan kekuatan, dukungan secara psikis maupun biologis. Konsep yang demikian memberikan kekuatan ataupun dukungan bagi seseorang yang mengalami sakit mental untuk siap berjuang, bertahan menghadapi diskriminasi, dan prasangka buruk dari orang lain. Apabila yang terjadi demikian maka agama ataupun spiritual memiliki peran yang penting bagi penderita sakit mental sebagai alternatif rehabilitasi. Menurut Lindgren dan Coursey bahwa dia telah melakukan interview pada pasien yang sedang mengalami program rehabilitasi psikososial. Sebanyak $80 \%$ mengatakan bahwa agama dan spiritual dapat membantu mereka. Menurut Trepper et al, menemukan bahwa partisipan yang mengalami gejala senang melakukan sesuatu yang kejam mereka senang menggunakan agama sebagai bagian dari terapi coping (Hefti, 2011).

Hasil penelitian yang dilakukan oleh Ellison \& Levin (Levin, 2010) menunjukan bahwa ada hubungan positif antara seseorang yang menjalankan agama dengan taat dan menjalankan spiritual dengan disiplin akan berefek pada kepuasan hidup. Penelitian yang dilakukan Krause (Cappellen, tth) bahwa spiritual dan agama berefek pada perasaan optimis dan kepercayaan diri yang baik. Penelitian yang dilakukan oleh Martos, Thege \& Steger (Cappellen, TothGauthier, Saroglou, \& Fredrickson, t.t.) bahwa spiritual dan agama berefek pada penerimaan makna hidup, dan penelitian yang dilakukan oleh Ai, Park, Huang, Rodgers \& Tice (Cappellen dkk., t.t.) bahwa orang yang menjalankan spiritual dan agama dengan baik memiliki harapan masa depan yang baik (Cappellen dkk., t.t.).

Beberapa review jurnal berkaitan dengan tema hubungan antara agama spiritual dengan kesehatan mental telah dipublikasikan. Hasil review dan meta analisis yang dilakukan oleh Donahue (Hackney \& Sanders, 2003) pada konsep-konsep agama dari Gordon Allport secara intrinsik yaitu keterkaitan agama dengan pemeluk itu sendiri, dan ekstrinsik yaitu interaksi antar pemeluk secara sosial. Hasil review dan meta analisis menunjukan bahwa ada hubungan 
yang positif antara pemeluk agama yang berorientasi secara ektrinsik dengan dua hal karakteristik yang dimiliki manusia yaitu prejudis dan takut mati. Sebaliknya tidak ada hubungan yang positif agama yang berorientasi intrinsik dengan dua karakteristik tersebut yaitu perilaku prejudis dan takut mati.

Hasil review dan meta analisis yang lain dilakukan oleh Bergin's (Hackney \& Sanders, 2003) pada literatur empirik berkaitan dengan hubungan antara perilaku agama dengan kesehatan mental. Hasilnya menunjukan bahwa pada umumnya ada hubungan positif antara agama dengan kesehatan mental. Hasil tersebut menunjukan bahwa beragama merupakan salah satu bentuk afiliasi untuk menumbuhkan fungsi-fungsi psikologi secara positif. Hasil review dan meta analisis yang lain dilakukan oleh Payne at al, (Hackney \& Sanders, 2003) menunjukan bahwa ada ambigu temuan keterkaitan agama dengan fungsi-fungsi psikologis bagi pemeluknya. Satu sisi ada temuan bahwa agama berpengaruh positif pada psikologi well being pemeluknya serta pencegahan adanya gangguan psikis pada pemeluknya. Sisi lain agama berpengaruh negatif terhadap pemeluknya. Hal tersebut terjadi karena perbedaan pemeluk dalam mengkonsepkan agama pada pribadinya.

Hasil penelitian menunjukan bahwa religiusitas berpengaruh terhadap kesejahteraan psikologis yang bersifat subjektif (subjective well being) orang-orang penganut jalan sufi (tarekat) dengan nilai t; 21, 219 dan $p: 0,000(p<0.001)$. Artinya bahwa religiusitas sebagai keagamaan yang bersifat formalistik yang dianut oleh perilaku sufi tarekat memiliki peran terhadap meningkatnya kesejahteraan psikologis seseorang yang bersifat subjektif. Apalagi perilaku sufi merupakan perilaku agama yang bersifat tersimpan, esensial, maka diasumsikan perilaku tersebut lebih memiliki peran terhadap kesejahteraan psikologis yang bersifat subjektif pada orang tersebut. Analisis penelitian tersebut dilanjutkan dengan variabel religiusitas, makna hidup sebagai variabel moderator terhadap kesejahteraan psikologis yang bersifat subjektif. Hasil penelitian menunjukan bahwa regression equation (2) dengan nilai standardize beta variabel religiusitas 0,657 (nilai p1), dan nilai standardize beta makna hidup 0,207 (nilai p3) dengan nilai semuanya signifikan. Nilai e1 menunjukan $=\mathrm{V}(1-0,690)=0,556$, dan nilai e2 menunjukan $=\mathrm{V}(1-0,703)=0,545$. Artinya bahwa makna hidup memenuhi syarat sebagai variabel moderator religiusitas terhadap kesejahteraan psikologis seseorang. Hasil tersebut 
menunjukan bahwa variabel makna hidup sebagai variabel moderator antara religiusitas dengan kesejahteraan psikologis seseorang yang bersifat subjektif pada perilaku sufi anggota tarekat Naqsabandiyah Khalidiyah Kebumen memenuhi syarat sebagaimana teori model regresi. Semakin tinggi religiusitas dan makna hidup anggota tarekat, maka akan semakin tinggi tingkat kesejahteraan psikologis anggota tarekat (perilaku sufi) (Saliyo, Koentjoro, \& Subandi, 2017).

Hasil review hubungan antara agama dan spiritual terhadap kesehatan mental menunjukan bahwa agama dan spiritual mampu menaikan kesehatan mental melalui religius coping secara positif, komunitas, dan dukungan serta keyakinan yang positif. Sebaliknya hasil penelitian juga menunjukan bahwa agama dan spiritual juga dapat merusak kesehatan mental. Hal tersebut terjadi apabila ada religius coping yang negatif, pemahaman yang salah terhadap agama, komunikasi yang salah dan salah pemahaman terhadap agama. Hasil review dapat disimpulkan bahwa agama ataupun spiritual dapat memperbaiki kesehatan mental serta merusaknya. Penjelasan yang demikian agar menjadi perhatian bagi praktisi agama ataupun spiritual sebagai sarana terapi terhadap kesehatan mental.

\section{Kesimpulan}

Uraian sebelumnya dapat disimpulkan bahwa agama dan spiritual dapat berpengaruh secara positif dan negatif terhadap kesehatan mental. Agama dan spiritual berpengaruh positif pada well being penganutnya dalam bentuk kesejahteraan psikologis seperti kepuasan hidup, rasa optimis, kreatif, ketenangan, kepercayaan diri dan rasa damai. Sisi lain agama dan spiritual juga dapat mencegah terhadap perilaku yang merusak pada diri yaitu ketergantungan terhadap obat terlarang dan perilaku berbuat kejam. Artinya dengan memahami ajaran agama dan spiritual perilaku merusak pada diri sediri dapat dihindarinya. Agama dan spiritual juga berpengaruh negatif terhadap pemeluknya dalam bentuk frustasi, stress dan lain sebagainya. Kejadian yang demikian terjadi karena adanya kesalahan menkonsepsikan ataupun mengkomunikasikan agama pada dirinya.

Perilaku sufi merupakan perilaku spiritual. Perilaku sufi berpengaruh pada otak 
seseorang. Ajaran ajaran sufi mengajarkan bagi pengikutnya untuk sering melaksanakan relaksasi. Seseorang yang sering melakukan relaksasi akan menyehatkan mentalnya dan baik well being orang tersebut. Hal yang demikian dapat disimpulkan bahwa perilaku sufi dengan kesehatan mental juga dapat positif. Efek perilaku sufi yang positif dalam kesehatan mental dapat dalam bentuk menemukan kepuasan hidup, makna dan tujuan hidup, kedamaian, ketenangan, rasa optimis, dan memiliki harapan yang baik dimasa yang akan datang. Sisi lain juga dapat berefek perilaku yang negatif dari perilaku sufi. Efek tersebut dalam bentuk kecemasan, stres, berperilaku kejam. Keadaan yang demikian terjadi karena salah pemahaman ataupun komunikasi terhadap ajaran sufi. Kesalahan yang lain karena dalam belajar sufi dimungkin tidak ada bimbingan yang baik.

\section{Kepustakaan}

Ahmed, D. S. (1993). Islam and the West: A Psychological Analysis. Sustainable Development Policy Institute.

al-Kurdi. (t.t.). Tanwirul Qulub. Semarang: Toha Putra.

Arkound, M. (1995). Rethingking Islam. Yogyakarta: Pustaka Pelajar.

Cappellen, P. ., Toth-Gauthier, M., Saroglou, V., \& Fredrickson, B. L. (t.t.). Religion, Well Being, and Positive Emotions. Journal of Happines Studies.

Cornah, D. (2006). The impact of spirituality on mental health: A review of the literature. Mental Health Foundation.

Hackney, C. H., \& Sanders, G. S. (2003). Religiosity and mental health: A meta-analysis of recent studies. Journal for the scientific study of religion, 42(1), 43-55.

Hefti, R. (2011). Integrating religion and spirituality into mental health care, psychiatry and psychotherapy. Religions, 2(4), 611-627.

Ikrar, T. (2015). Ilmu Neurosains Modern. Yogyakarta: Pustaka Pelajar.

Koenig, H. G. (2001). Religion and medicine II: Religion, mental health, and related behaviors. The International Journal of Psychiatry in Medicine, 31(1), 97-109.

Kosshal, T., Kolahdouzan, A., \& Sharifi, G. (2013). Religion and Spirituality at The Spirituality Oriented Mystic and Psychologists. Interdiciplinary Journal of Countemporary Research in Business, 4(11).

Levin, J. (2010). Religion and mental health: Theory and research. International Journal of Applied Psychoanalytic Studies, 7(2), 102-115.

Pasiak, T. (2015). Membangunkan Raksasa Tidur, Optimalkan Kemampuan Otak Anda dengan Metode ALISA. Jakarta: Gramedia Pustaka Utama.

Plante, T. G. (2008). What do the spiritual and religious traditions offer the practicing psychologist? Pastoral Psychology, 56(4), 429-444. https://doi.org/10.1007/s11089-008-01190 . 
Saliyo. (2017). Bimbingan Konseling Spiritual Sufi dalam Psikologi Positif. Yogyakarta: Galang Press. Saliyo, Koentjoro, \& Subandi. (2017). The Influence of Religiosity, Meaning of Life Towards Subjective Well Being of Participants Naqsabandiyah Khalidiyah tarekat in Kebumen Indonesia. Journal of Humanities and Social Science, 22(4).

Shihab, Q. (1992). Membumikan Al-Qur'an. Bandung: Mizan.

Thouless R. H. (1995). Pengantar Psikologi Agama. Jakarta: Raja Grafindo Persada.

Yamani, A. A. U. A. A. (2010). Intambih !! Dinuka fi Khotor. Jamaah Tadarus Surat Yasin Desa Petanahan. 